\title{
Meeting Room Reservation Mobile Base System for PT. Visionet Data Internasional
}

\author{
Ade Setiadi $^{1}$, Fifit Alfiah ${ }^{2}$, Fajar Septiawan ${ }^{3}$ \\ ${ }^{1,2,3}$ Teknik Informatika - Universitas Raharja \\ E-mail: ${ }^{* 1}$ adesetiadi@ raharja.info. ${ }^{2}$ fifitalfiah@ raharja.info, ${ }^{3}$ fajar.septiawan@ raharja.info
}

\begin{abstract}
Reservation Meeting Room System is a system that is used to reserve meeting rooms in real time in all offices of PT. Visionet Data Internasional, so that this system is easy for employees to use, there is no duplication of reservations for meeting rooms between employees, and can be used through employees' mobile devices. PT Visionet Data Internasional is a company engaged in the field of IT Consultants consisting of many departments that focus on the development and maintenance of software and hardware, with many departments using meeting rooms very intensely, obtained information systems used to book meeting rooms are inaccurate, not real time, complicated, and frequent duplication of orders. Therefore the system that will be created by the author is a renovation and update of the previous system that already exists at PT. Visionet Data Internasional. It is expected that with this system, it can minimize errors that occur in the previous system. This system is also expected to make it easier for all employees to book a meeting room at PT Visionet Data Internasional.
\end{abstract}

Keywords - Meeting Room Reservation, Realtime, Mobile Application.

\section{INTRODUCTION}

An advanced company must have plenty of meeting rooms to exchange ideas, weekly reports for each department, or meetings with clients. Having a meeting room is very important for the smooth running of company activities. In the sector of human life the most widely implemented information systems are companies. In every company will always try to implement an effective information system to achieve company goals. Not only for the sake of increasing profits alone, a company must have supporting utilities for the smooth resolution of problems by exchanging ideas in a place that is, a meeting room.

As the development of information and communication technology advances, business competition in the industrial world is getting tougher. The number of companies is increasing and continuing to do business and strategy in maintaining business. Behind all that are talents - talents who are trying to advance the company by exchanging ideas, finding solutions to a problem, making the best business plans in the same room. ${ }^{[1][2]}$

Based on the background description, the authors conducted a study entitled "Meeting Room Reservation Mobile Base System for PT. Visionet Data Internasional" so that the meeting room booking process can facilitate all employees based on mobile devices by presenting information directly and quickly (realtime).

PT Visionet Data Internasional has a system that is already running, but still relies on third parties who are united with Zimbra mail clients. The application is still web-based and is focused on managing email needs. In addition, there are features to book a meeting room that still has some shortcomings.

Less informative about meeting room availability information, so users cannot see information that the room has been used by other users. Filling in the location or meeting room does not present information on the meeting room itself, the user must manually type the desired meeting room and the room is made as an email address for example: Bima Room, then the user must fill in bima.room@visionet.co.id manually.

Information is not realtime, meaning when the customer has successfully filled out the reservation form, the customer must wait for a response from the Bima Room that the request is 
successful or failed. Then if the request fails, the user is required to fill in the reservation form from the beginning ${ }^{[2]}$.

Frequent duplication of orders. Because the presentation of information is not yet realtime, many customers make reservations at the same time, the incident in the field is, when the customer has received approval there is another customer who comes to confirm that he has booked the room at the same time.

\section{RESEARCH METHODS}

\subsection{Research Methods}

The method used in this step the authors do several ways to get information that can be collected as research material including, namely:

\section{1) Analysis Method}

This method is done to analyze the procedures that are already running in the company. Analysis is carried out to determine the efficiency of the procedures that have been carried out. Lack of procedures that have been run will be a reference for making new procedures using a computerized system.

2) Design Method

Using the Unified Modeling Language (UML) method which will be outlined in the stages: making Use Case Diagrams, Sequence Diagrams, and Activity Diagrams, as well as elaborating the prototype design and data specifications, which use several software in its design including: Draw IO, and Adobe XD.

3) Development methods prototype

Prototype is the process of making a simple software model that allows the user to have a basic overview of the program and conduct initial testing. Prototyping provides facilities for developers and users to interact with each other during the manufacturing process, so that the bomber can easily model the device to be made.

The following are the stages of the prototype development method, which begins with gathering needs, involving developers and system users to determine the objectives, functions and operational requirements of the system.

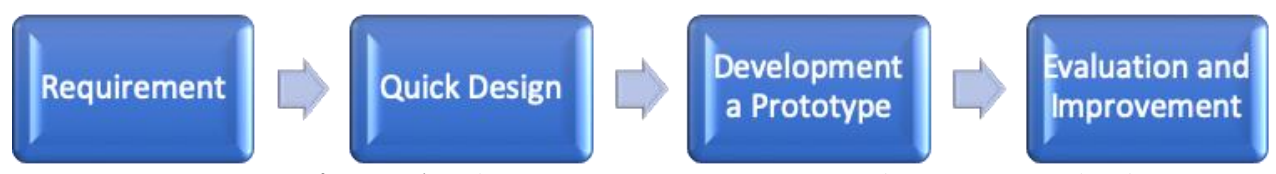

Figure 1. The Prototype System Development Method

The steps in the prototype method are as follows:

a. Collection of Needs

Collecting needs involves meeting the developer and the customer to determine the overall purpose for which the software is built; identify needs in the form of an outline of the basic requirements of the system to be made.

b. Fast design process

Rapid design leads to the construction of prototypes whose design focuses on representing aspects of the software from the user's point of view.

c. Development a prototype

Build prototypes by making temporary designs that focus on serving customers including input, process and output formats.

d. Evaluation and improvement

This stage of the prototype is evaluated by the user or client, whether the prototyping that is built is in accordance with the wants and needs of the customer or not. If it does not match, the prototyping will be revised by making improvements and repeating the previous steps. But if it is suitable, then the system can be used. 


\subsection{Theoretical Basis \\ A. Definition of Meeting}

A meeting is a meeting or gathering of at least two or more people to decide on a goal. Meetings can also be used as a medium for communication between people or office leaders with their staff ${ }^{[3]}$. Meetings are also defined as face-to-face group communication media by many organizations whether private or government. Meetings are often used as a person or group of people to bring together thoughts to carry out certain matter. In another sense the meeting can also be interpreted as a collection of groups of people who are formal in nature by involving four or more people with the aim of communicating, planning, determining policies, making decisions, and providing motivation. The final objective of the meeting is to bring meeting participants directly for communication, so that meeting participants can contribute directly to the conversation so that ideas for resolution of problems can be conveyed directly, so that meeting participants can be stimulated directly in understanding each problem encountered, so that meeting participants can both contribute in achieving certain goals. (State Administration Institution. Directorate of Widyaiswara Development: the importance of meeting).

\section{B. Definition of Realtime Application}

According to Erick Kurniawan and Reza Faisal ${ }^{[4]}$. Real-time application (Real-Time Application (RTA) is an application program that has a function during the time range that the user feels directly or occurs at that moment.

On the official website of Microsoft Dotnet Signal R, explained "Today's modern apps are expected to deliver up-to-date information without hitting a refresh button. Add real-time functionality to your dashboards, maps, games and more. What is real-time functionality? It's the ability to have your server-side code push content to connected clients as it happens, in real-time".

\section{Definition of Mobile Application}

According to Ir. Yuniar Supardi, Mobile applications are categorized into 2 according to the development technology used ${ }^{[5]}$ :

1) JQuery Mobile.

JQuery is a library that uses a javascript interface that simplifies searching documents, events, animations, and interactions. JQuery Mobile is a javascript library that emphasizes UI (User Interface) between Javascript and HTML. JQuery Mobile works on all smartphones using HTML5 and CCS3.

2) Native Application

Native Application is an application made specifically for a particular operating system, such as Android, IOS, or Blackberry.

\section{Definition of Information}

According to Nur Azizah, et al in the SENSI journal the quality of information depends on 3 (three) things, i.e. information must be accurate, timely and relevant. A description of the quality of the information is presented below ${ }^{[6]}$ :

1) Accurate, information must be free from mistakes and not misleading. Accurate also means that information must clearly reflect the intent. Information must be accurate because usually from the source of information to the recipient of information there is the possibility of interference that can change or damage the information.

2) Timelines, Information that comes to the recipient must not be too late. Information that is outdated will no longer have value because information is a basis for decision making. If decision making is too late, it can have fatal consequences for the organization.

3) Relevance, This information has benefits for the user, where the relevance of information for each individual is different depending on who receives and who needs. The value of information is determined by two things: benefits and costs. An information is said to be valuable if its benefits are more effective than the costs of obtaining it. 


\subsection{Literature Review}

Literature Review conducted by researchers to find out the initial foundation and as a support for research activities to be carried out by researchers so as to avoid repeating the same thing in research and be able to develop to a higher level in order to perfect or complement existing research. The following are research that has been done and has correlation with the research that will be discussed in this Job Training Class:

1. Research conducted by Dwi Utari, et al. with the title "Application of Ordering the Palembang-based Grand Atyasa Convention Center Using the Performance, Information, Economic, Control, Efficiency, Service (Pieces) Framework" Method and research results create an application that can make it easier for customers to make a building reservation and provide convenience for the Grand Atyasa Convention Center in controlling the ordering and management of existing data on the Grand Atyasa Convention Center ${ }^{[7]}$.

2. Research conducted by Fakhrunnisa, et al with the title "Application Management for Hotels Reservation in Bandung on a Web-Based" and the results of the research Application Management for Hotels Reservation in Bandung Based on Web is an application used to help hotel submissions by the hotel, hotel management by admin, both room data management, facility data, and transactions, and help the reservation process that takes place at the hotel by the customer online ${ }^{[8]}$.

3. Research conducted by Karimah, et al. with the title "Design And Development Of Results Application System Of Muhammadiyah Al-Huda Masjid East Tebet" and the results of audit hall application research such as tenant data reports, booking data, payment data, cancellation data per period, as well as booking proof reports, proof of payment, and proof of booking data-Ian, which can facilitate the hall admin in processing the data because the data is stored in a database neatly, orderly, and safely ${ }^{[9]}$.

4. Research conducted by Nur Elpan, et al. with the title "Design and Implementation of Boarding House Promotion Application in Palembang City Based on Mobile" and the results of research designing and implementing a boarding house promotion application in Palembang based on mobile using Android. This application can help boarding owners promote boarding houses and vice versa provide convenience and comfort to boarders ${ }^{[10]}$.

5. Research conducted by Akbar Reynaldo, et al with the title "Making Gis Applications for Android-Based Multipurpose Building Spread (Study: Malang City)" and the results of this application research have a menu of choices based on districts. This application has 36 points spread in the city of Malang. Where this application can facilitate the public in finding building rentals with complete and accurate information, and as a material consideration in choosing a building as a place to hold events ${ }^{[11]}$. 


\section{RESULTS AND DISCUSSION}

\subsection{Research Flow}

The research flow is a procedural chronological structuring or a continuous methodological relationship. One of the objectives of using a research flow is to keep the focus on the problem and make it easier to achieve research objectives. It is also hoped that linkages and sustainability can be maintained at each of the stages of the research.

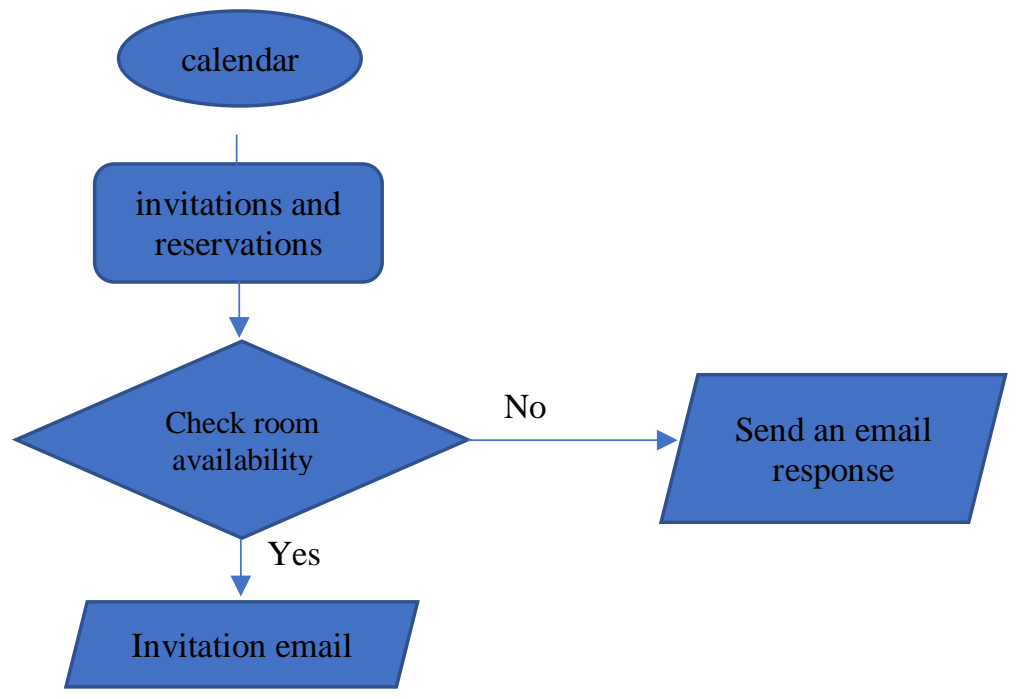

Figure 2. Research Flow

\subsection{SOLUTIONS TO PROBLEM}

From the results of observations made, researchers found several problems from the system running at PT. Visionet International Data in the part of the system that is already running, namely meeting room reservations that still have complicated use constraints, are not realtime and are not user friendly to Observation of the running system:

a. Calendar Page

In the picture information below, there is no spatial information that is being used on certain hours and days, so the information presented is not realtime.

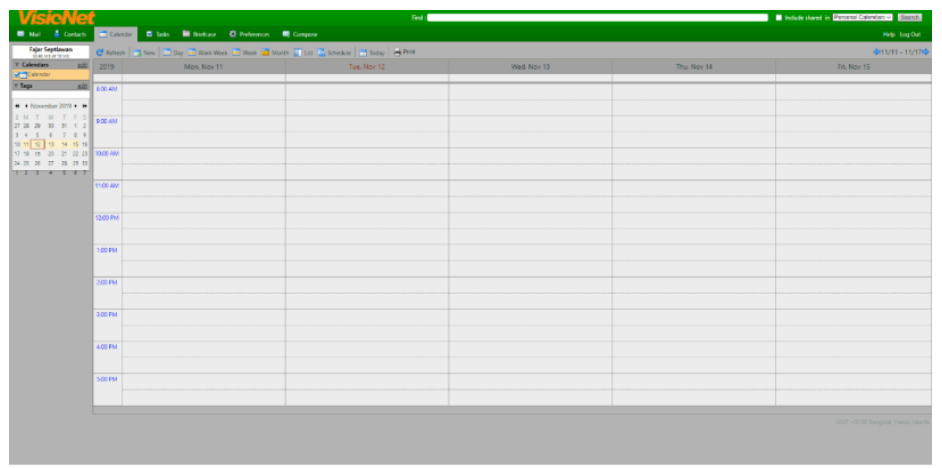

Figure 3. Calendar Page

Then press "New" shown in figure 3 to make an invitation and reserve a meeting room. From here it can be seen, the placement of small buttons and poor location, can make it difficult for new users. 
b. Invitation Page

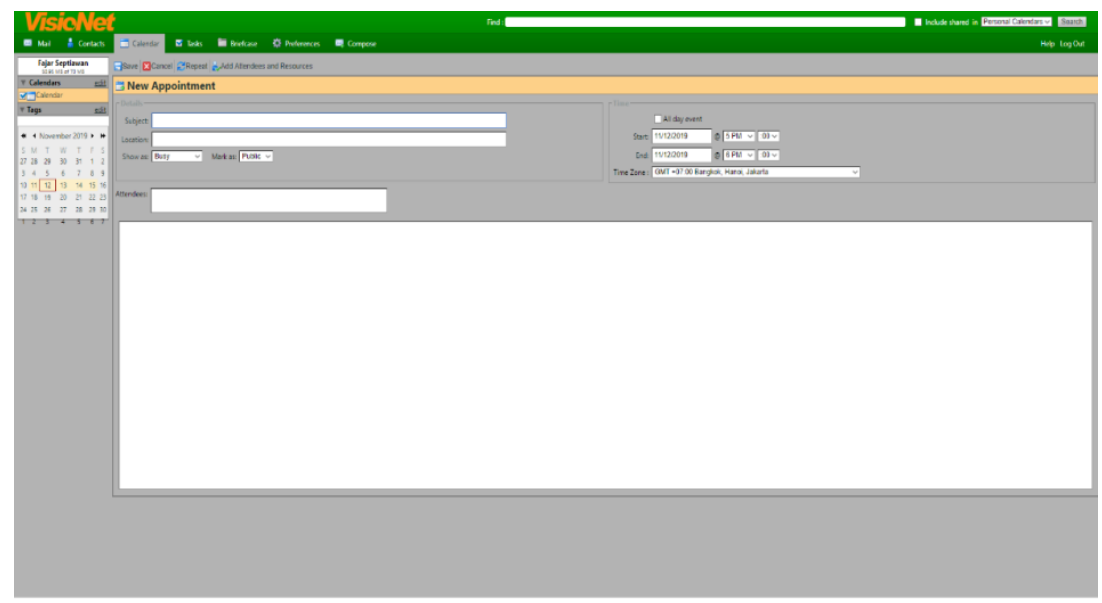

Figure 4. Invitation Page

In figure 4 there is a form to fill out invitations. By filling in important inputs, including :

1) Subject : The title of the e-mail that will be sent to the invitation present.

2) Location : Select the location of the meeting room.

3) Show as : Types of meetings (Free, Tentative, Busy, and Out of Office)

4) Mark as : Intended for private or public

5) Attendees : Give invitations to coworkers who are at PT Visionet Data InternasionalTime :

a. Start : Start time.

b. End : End Time.

c. Time zone: Specified time zone.

From the information on the form above and the testing done by researchers, it can be concluded that:

1) Filling in the location of the room does not automatically present what meeting room information is available.

2) Cannot select the date on the invitation page, if you want to change the date, the user must return to the calendar page and refill the invitation form.

3) When filling out the time form, there is no time information that has been used in the selected room.

c. Submit Invitation

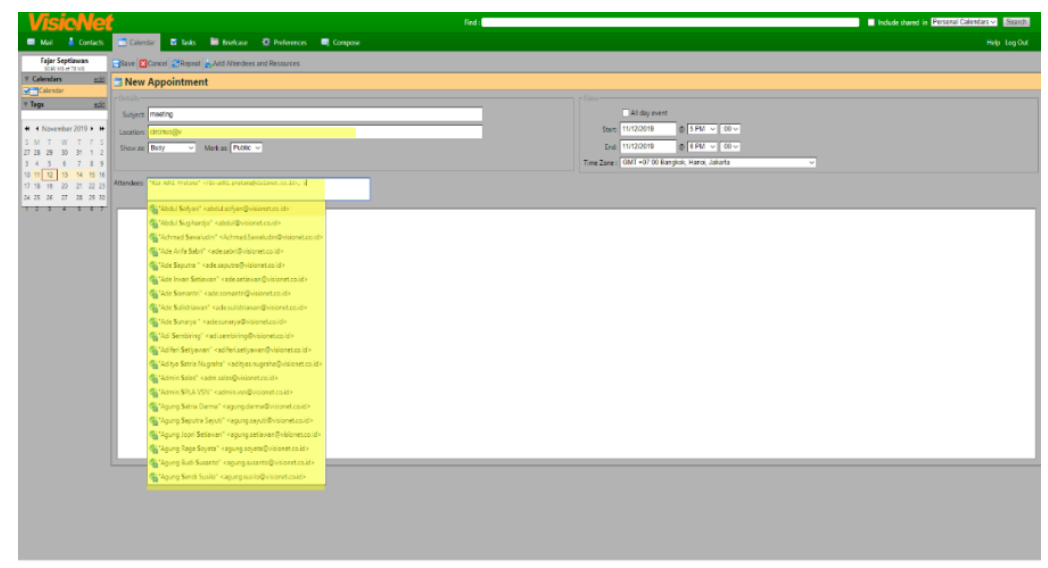

Figure 5. Form Input Invitation 
During the test in figure 5, the researcher did not get direct information explaining that the researcher obtained approval to use the room. The researcher must wait for an email reply from the room explaining that, the room is available at the time the researcher wants.

d. Response Result

The results of the response will be sent after sending an invitation to the participant and the room will be in the form of an email.

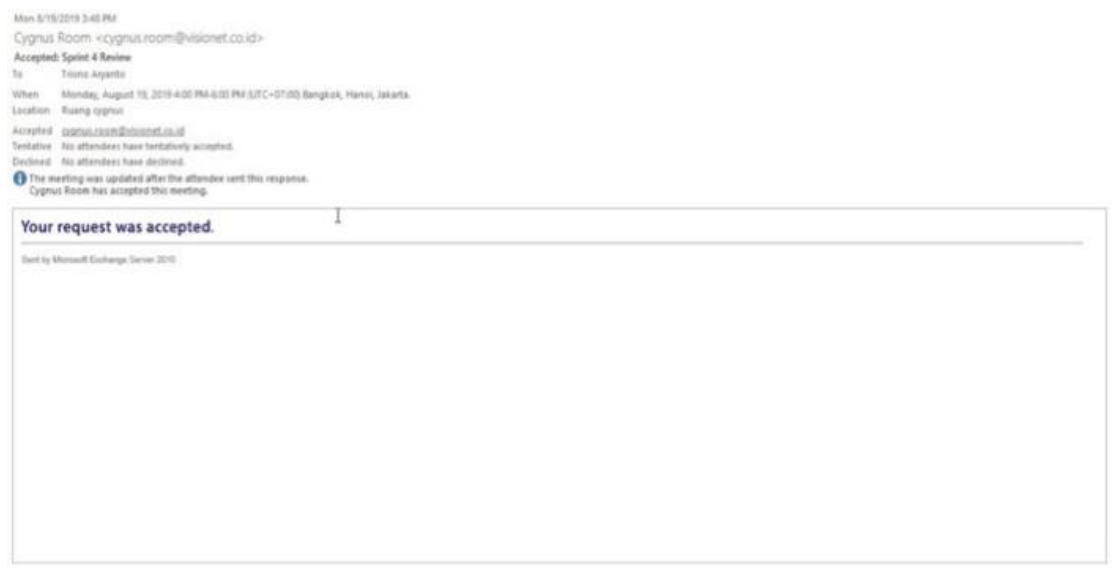

Figure 6. Response Accepted

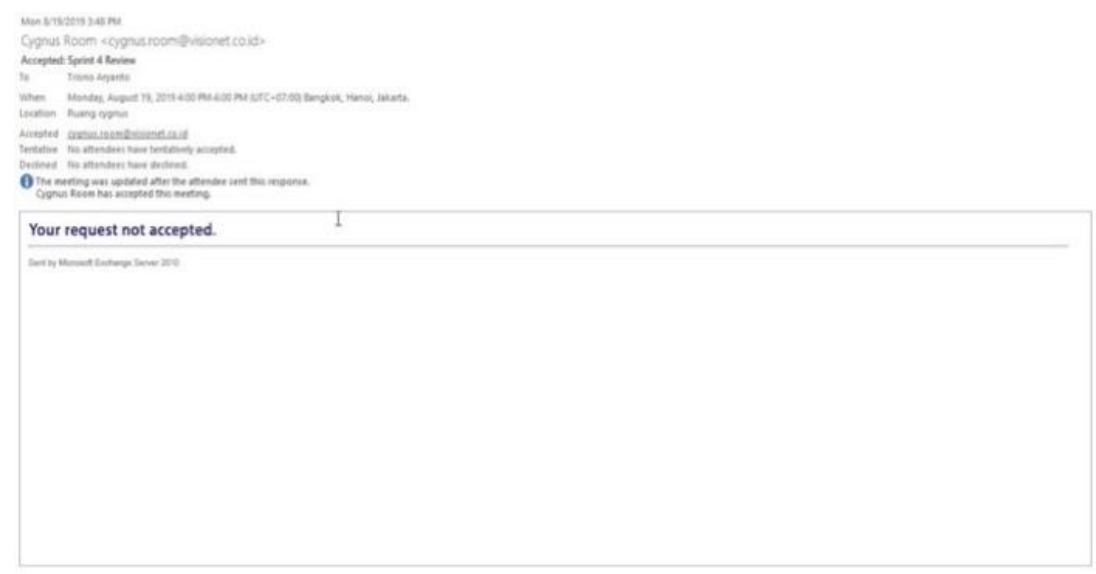

Figure 7. Response Rejected

From the results of feedback figure 6 and 7, the researcher concludes that if the desired reservation is rejected, the researcher is required to refill from the first step. This can be difficult for users when rejected. 
3.2 System Design Model Design

A. Use Case Diagram

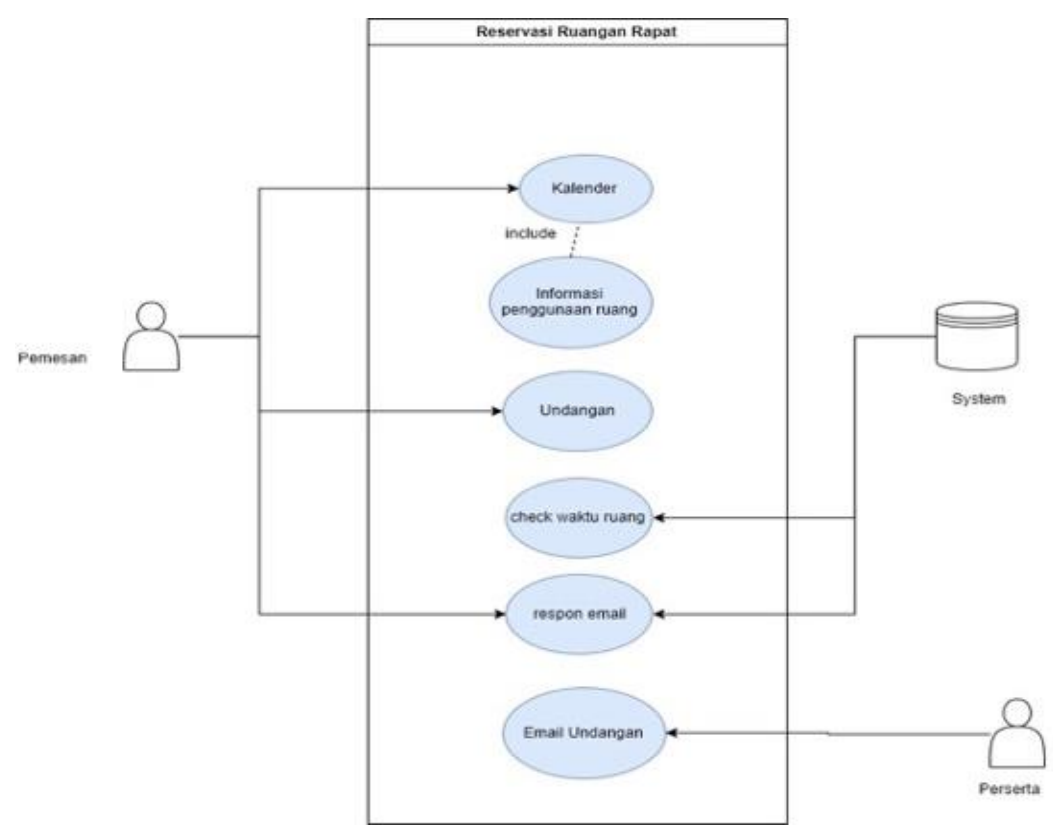

Figure 8. Use Case Diagram

In figure 8. A picture of the Use Case Diagram of the system that runs on PT Visionet Data Internasional, starting with the customer who wants to make a reservation by choosing a date on the calendar, followed by making an invitation to the participant. Then the system will check the availability of the room and send a response to the customer. A successful response will send an email to the participant.

\section{B. Activity Diagram}

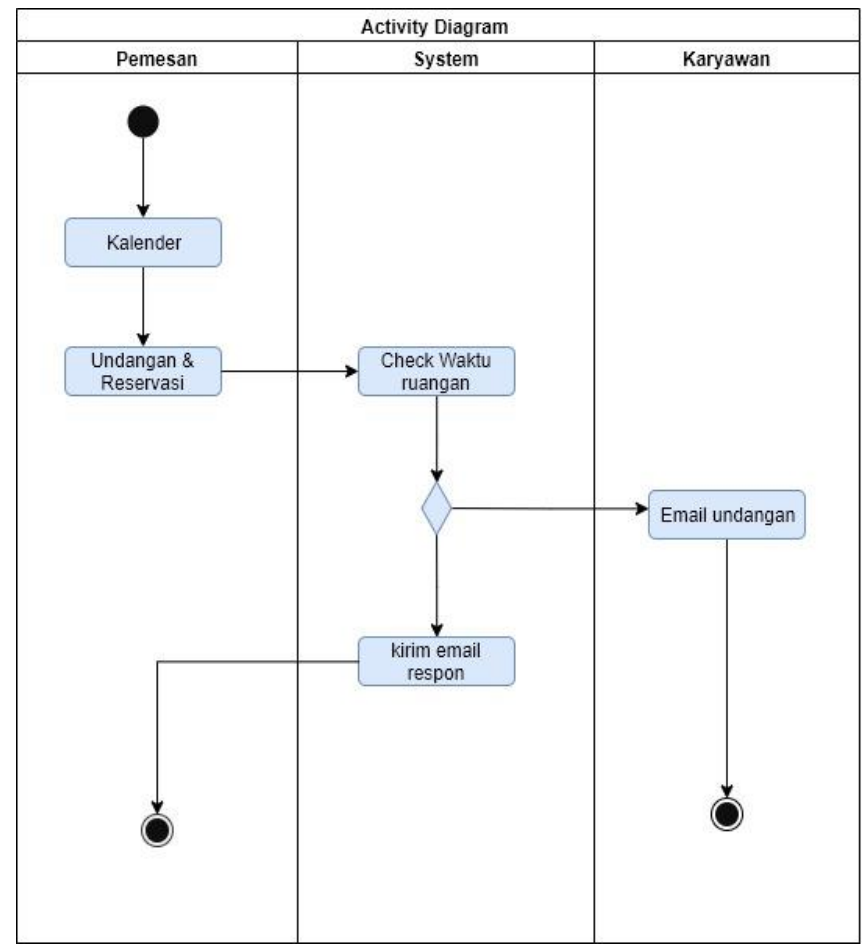

Figure 9. Activity Diagram

In figure 9. Is a picture of the Activity Diagram of the system that runs on PT Visionet Data Internasional has 1 (One) Initial Code starting from the customer who opens the calendar page, chooses the date then makes an invitation followed by a system that checks the time of the 
room, then a successful decision will send an email to participants and until the activity is complete, and the decision fails the system will send a response email to the customer.

\subsection{IMPLEMENTATION}

The implementation of the Meeting Room Reservation system at PT Visionet Data Internasional was developed with an Android and iPhone-based mobile platform. All users can book a room anywhere at any time with a view that is easier to use compared to an existing system that is still web based.

a. Prototype Screen Login

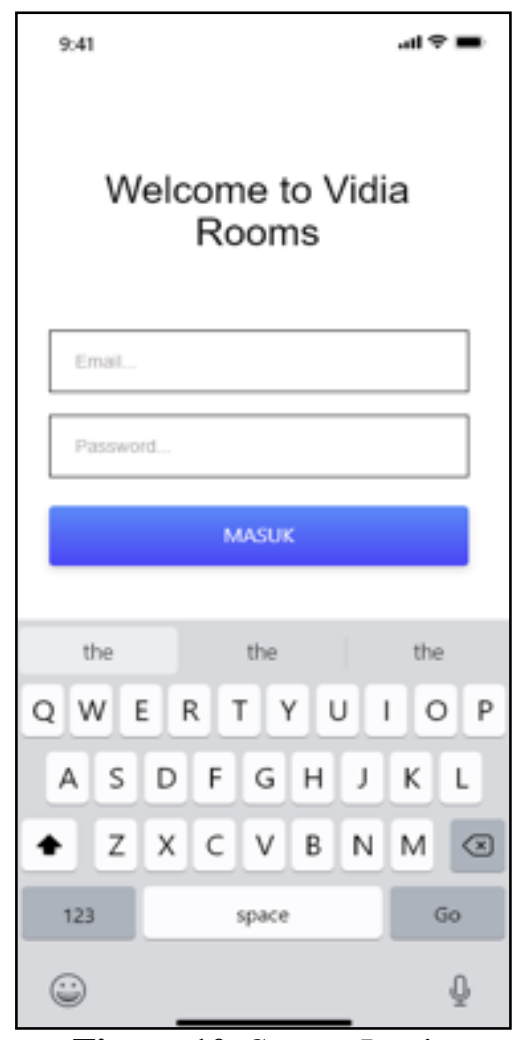

Figure 10. Screen Login

In Figure 10. The Login Screen contains 2 pieces of text input to enter a user's email and password and a button to enter the application. 
b. Prototype Screen Home

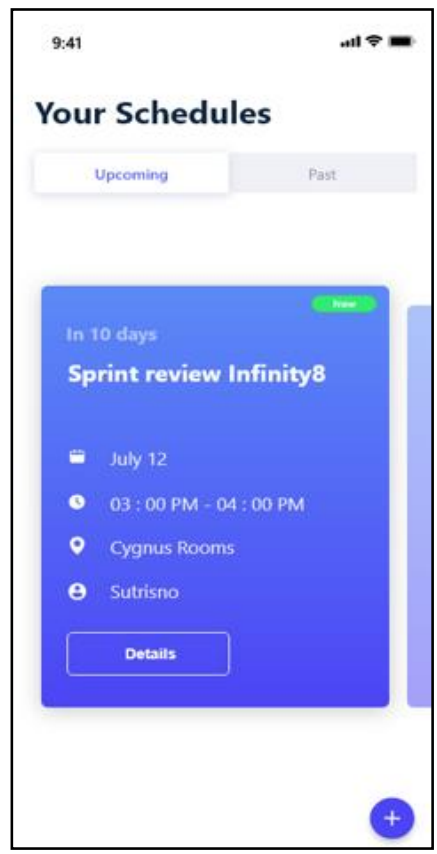

Figure 11. Screen Home

In Figure 11. The screen home contains information on upcoming schedules, categorized as going to data (upcoming) and past (past). This page is intended for customers and attachments. In the lower right corner there is a button to add a new schedule.

c. Screen Detail Invitation

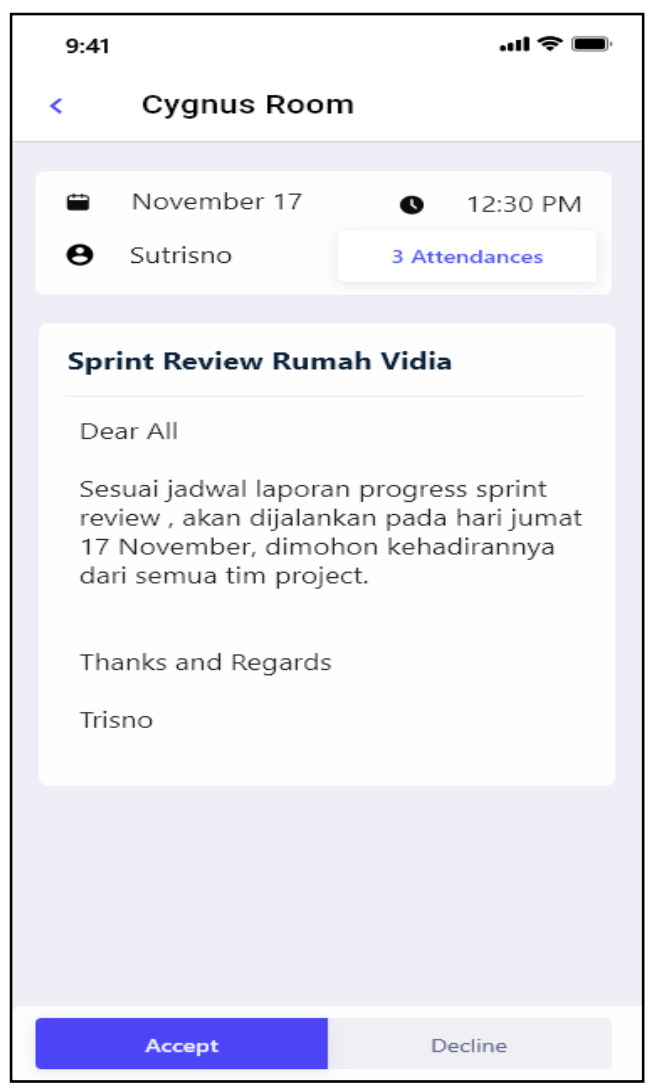

Figure 12. Screen Detail Invitation

In the invitation detail screen displays detailed information including the contents of the message made by the customer. At the bottom there are 2 Accept and Decline buttons. 
d. Prototype Popup Decline

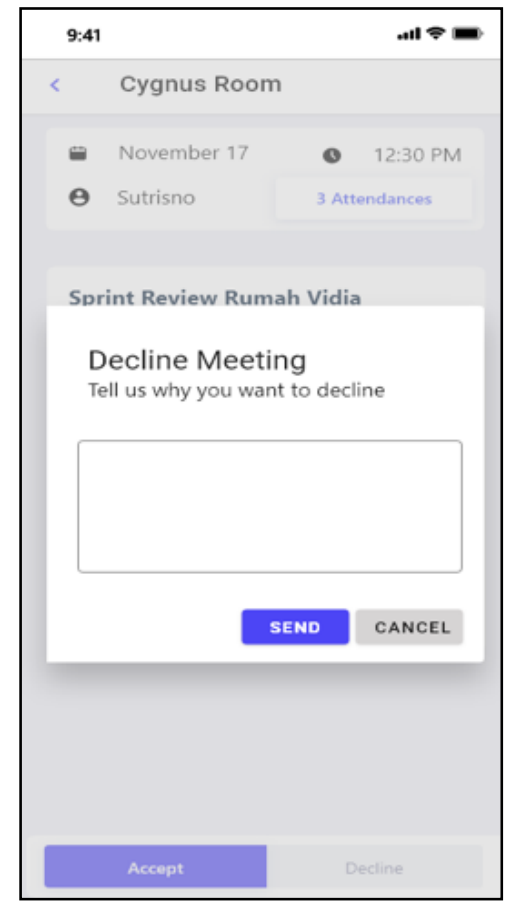

Figure 13. Decline Popup

When the user wants to decline the invitation, the user can press the Decline button, after that it will display a popup form and there is an input field to fill the reason for the rejection.

e. Prototype Response Message

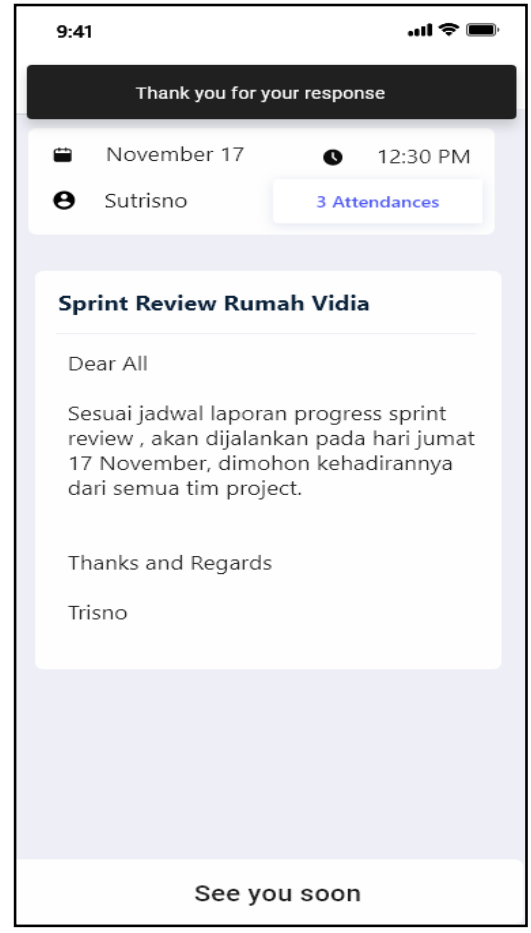

Figure 14. Response Rejected

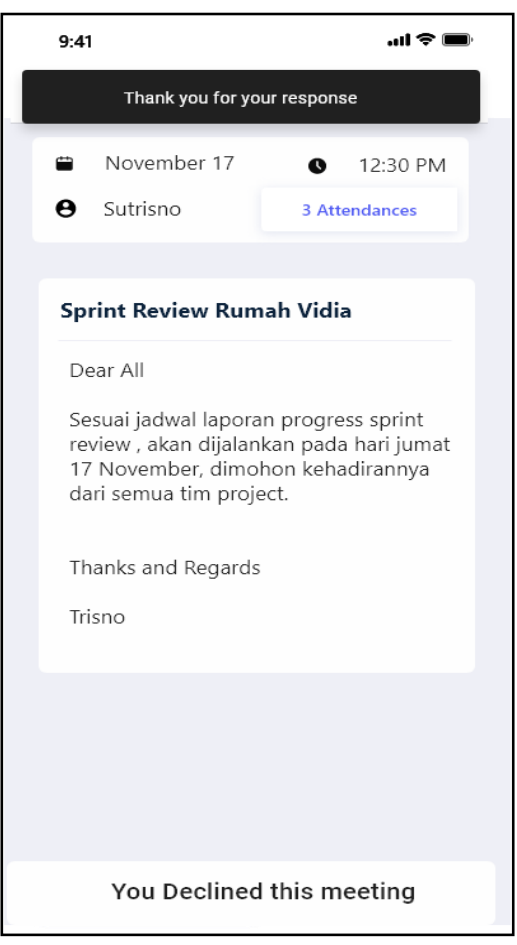

Figure 15. Response Accepted

In the picture above is the response when the participant rejects the invitation (Figure 14) and accepts the invitation (Figure 15). 
f. Reservation Form

1) Prototype step 1 screen select the room

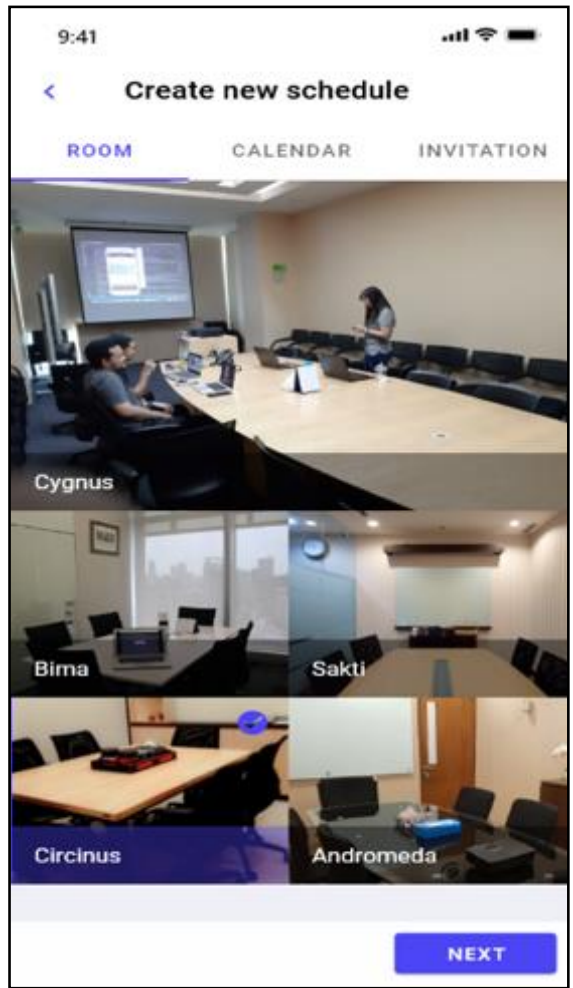

Figure 16. Screen choose room

In the first step, the user is required to choose the desired room, then click next to proceed to the next stage.

2) Prototype step 2 calendar screen

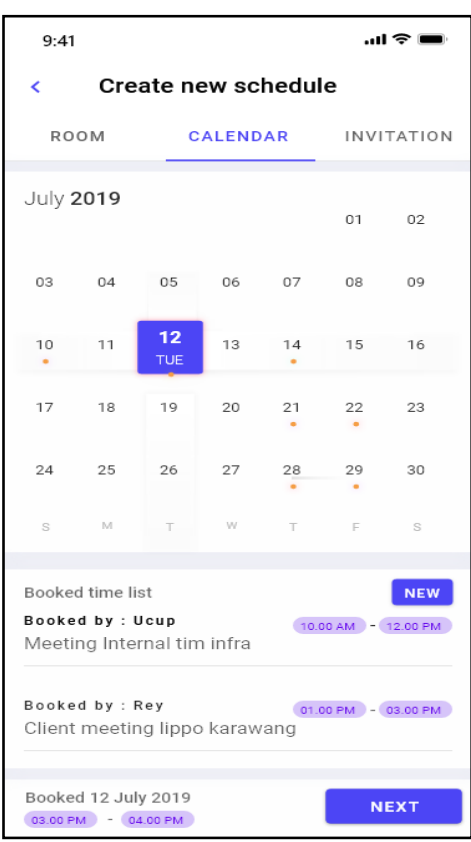

Figure 17. Calendar

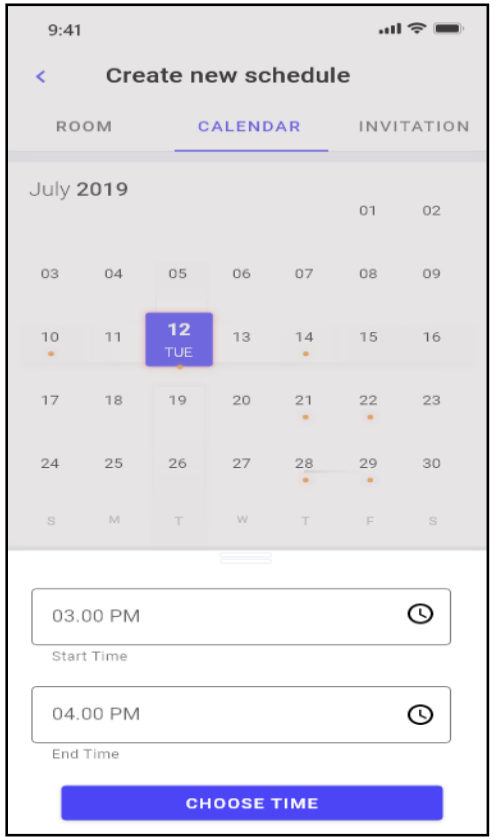

Figure 18. Timepicker

In this screen there is a calendar used to select the desired date. There is an orange under the date number, indicating that the date there are other users who order on that date and are displayed at the bottom. After selecting the date click the new button to select the desired time shown in Image 18. 
3) Step 3 invitation screen

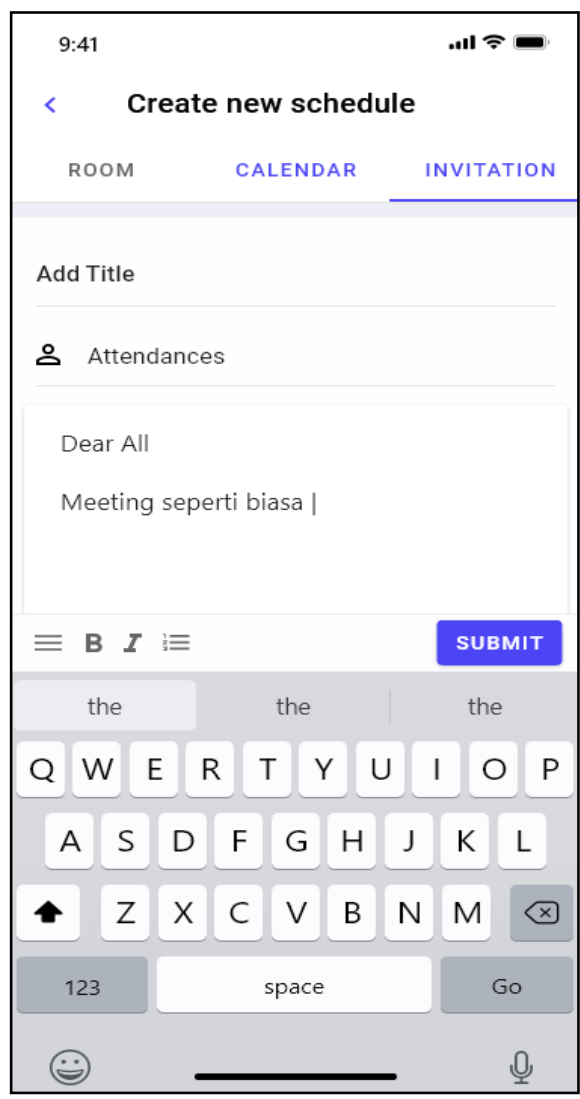

Figure 19. Invitation Screen

In this screen there are 3 (three) input fields, namely, titles, attendaces, and message descriptions. This form aims to fill out invitations that will be sent to employees (Attendances) in the form of e-mail and displayed as detailed invitation information.

\section{CONCLUSION}

Based on the analysis of the system that has been carried out at PT Visionet Data Internasional that has been done, it can be concluded, the reservation process already has a system but still has some deficiencies, such as not providing accurate information and the reservation process already has a system but still has some deficiencies, like haven't provided accurate information.

\section{SUGGESTED}

Suggestions that can be given in this research for further development in the future are, It is necessary to re-develop with the latest technology that is able to run computerization more effectively, efficiently, quickly, and accurately. There needs to be a change in the flow of the system to speed up or shorten the process of making a reservation without removing the desired process flow goals such as the reservation process.

\section{REFERENCES}

[1] M. Tigaraksa, "Analisa dan Perancangan Aplikasi Gedtix untuk Pemesanan Gedung Pendahuluan Studi Literatur Metodologi," vol. xx, no. x, pp. 18-25, 2018.

[2] P. T. Akhir and P. R. Prakasa, "Naskah publikasi rancang bangun sistem pemesanan dan kustomisasi souvenir secara online berbasis website," 2020. 
[3] P. A. Sunarya, E. Febriyanto, and J. Januarini, "Aplikasi Mobile Absensi Karyawan Dan Pengajuan Cuti Berbasis GPS," vol. 12, no. 2, pp. 241-247, 1978.

[4] N. Azizah, S. Rahayu, and B. Undari, "Prototype Android Based Payroll Monitoring Application at PT . Anugrah Distributor Indonesia," vol. 13, no. 1, pp. 56-63, 2020.

[5] D. Mukti, A. Lesmana, M. Device, and B. Inggris, "Pemanfaatan Aplikasi Mobile Android Sebagai Media Pembelajaran Dan Latihan Bahasa Inggris Untuk Sekolah."

[6] N. Azizah, S. Rahayu, and N. Adhista, "Perancangan Sistem Informasi Penilaian Kinerja Karyawan Spg Berstatus Kontrak Pada Pt . Softex Indonesia Menggunakan Metode Simple Additive Weighting ( SAW )," vol. 3, no. 2, pp. 182-189.

[7] D. Utari et al., "Aplikasi Pemesanan Grand Atyasa Convention Center Palembang Berbasis Android Menggunakan Metode Performance , Information , Economic , Control , Eficiency , Service ( Pieces ) Framework."

[8] F. N. Afra, H. Nugroho, S. Si, and E. Rosely, "Aplikasi Pengelolaan Reservasi Hotel Di Bandung Berbasis Web," vol. 4, no. 3, pp. 1686-1692, 2018.

[9] A. Susanto, U. Pauziah, P. S. Informatika, K. Gedong, P. Rebo, and J. Timur, "Rancang Bangun Sistem Aplikasi Reservasi Aula Masjid Al - Huda Muhammadiyah Tebet Timur," vol. 01, no. 03, pp. 398-404, 2020.

[10] S. G. I. Mdp, "Perancangan dan implementasi aplikasi promosi rumah kost di kota palembang berbasis mobile," no. x, 1978.

[11] R. A. Ramadhan and D. K. Sunaryo, "Serbaguna Berbasis Android ( Studi kasus: Kota Malang )." 